29. Centers for Disease Control and Prevention. National public health performance standards program: state public health system performance assessmenti. Atlanta, GA: CDC, 2001. Available online at www.phppo.cdc.gov/nphpsp/Documents/ State_v_1_OMB_0920-0557.pdf. Accessed 7 January 2004.

30. Centers for Disease Control and Prevention. National public health performance standards program: local public health system performance assessment instrument. Atlanta, GA: CDC, 2001. Available online at www.phppo.cdc.gov/nphpsp/ Documents/Local_v_1_OMB_0920-0555.pdf. Accessed 7 January 2004.

31. Davis RM. Measuring the performance of public health agencies. Government, like doctors and hospitals, should meet quality standards. $B M J 1999 ; 318: 889-890$.
32. Centers for Disease Control and Prevention. State public health preparedness and response capacity inventory. Version 1.1. Atlanta, GA: CDC, 2002. Available online at www.phppo.cdc.gov/od/inventory/index.asp. Accessed 7 January 2004.

33. Davis LM, Blanchard JC. Are local health responders ready for biological and chemical terrorism? RAND Document No: IP-221-OSD. Santa Monica, CA: RAND Center for Domestic and International Health Security, 2002. Available online at www.rand.org/cgi-bin/Abstracts/ordi/getabbydoc.pl?doc=IP221-OSD. Accessed 7 January 2004.

34. O'Toole T, Mair M, Inglesby TV. Shining light on 'dark winter'. Clin Infect Dis 2002; 34: 972-983.

35. Davis RM. Healthy people 2010: objectives for the United States. BMJ 2000; 320: 818-819.

\title{
DEVELOPMENT OF A STANDARDISED REGIONAL REPORT FROM THE NSW HEALTH SURVEY PROGRAM
}

\section{Maria Torres \\ NSW Public Health Officer Training Program \\ NSW Department of Health}

\section{David Muscatello}

Program for Enhanced Population Health Infostructure NSW Department of Health

\section{Margo Eyeson-Annan \\ NSW Health Survey Program \\ NSW Department of Health}

The area health services require population health data at the local level, to monitor the health of their populations, plan services, and develop policy. The NSW Health Survey Program is one of the main sources of population health data in New South Wales. In 2002, as part of the program's reporting strategy, a standardised regional report was developed to meet local reporting needs. This article describes the process of developing a template for a standardised form of regional report for each area health service.

\section{BACKGROUND}

NSW Health provides health services through area health services that plan, deliver, and coordinate local health services within their regions. This service model aims to strengthen local commitment to disease prevention and population health. ${ }^{1}$

The Health Survey Program is one of the main sources of population health information in NSW. Since its inception in 1996 until 2001, 2 adult health surveys were conducted, ${ }^{2}$ which had adequate numbers to provide estimates for each area health service. ${ }^{3}$ From 2002, a continuous health survey was implemented, with a yearly sample of approximately 800 adults from each area health service. $^{4}$

Population health information at the local level is necessary for areas to monitor the health of their populations and to support policy development and planning. Areas vary in their capacity to access health survey data and using that data to develop their own reports. Formal and informal consultation with area staff by the Centre for Epidemiology and Research highlighted the need for summaries of local level data to be made available to the areas in both printed and electronic form, ${ }^{5,6}$ with access to downloadable graphics and data tables so that areas could prepare their own reports. Our aim was to develop a standardised regional report for each area that would meet state and local reporting needs.

\section{METHOD}

First, we developed a draft template for a regional report and a questionnaire for consultation. Second, using the draft template and the questionnaire, we consulted with the areas to determine the appropriateness of the regional report to meet their population health information needs. Finally, we used the feedback to finalise the regional report template.

\section{Development of the regional report draft template and questionnaire}

The regional report draft template was developed by considering data available from previous surveys, data limitations, the resources required to produce the reports, ease of interpretation, and previous consultations with 
the areas regarding their information needs. The NSW Department of Health had identified a series of key indicators for surveillance and planning purposes. ${ }^{1}$ Key indicators available from the Health Survey Program from 1997, such as self-reported health status and health risk factors, were included in the draft template (Table 1).

The regional report draft template included an introduction page that described the aims of the reports and gave a list of possible indicators, and an example page showing how the graphs and tables for each indicator would be presented for males and females and for different age groups.

The self-completed questionnaire included the following questions:

- How easy to understand do you find the sample report?

- In your experience with health service planning and development staff in your area, how easy to understand would they find the sample report?

- In your experience with policy development staff in your area, how easy to understand would they find the sample report?

- How do you think the presentation of the information could be improved in order to make it easier to understand?

- What other topics from the Survey would you like reported at the area level?

- In your opinion, how useful would these reports be for monitoring the health of the population in your area?

- In your opinion, how useful would these reports be for planning and development of health services in your area?

- In your opinion, how useful would these reports be for development of population health policy in your area?

- Do you have any other comments?

\section{Consultation with the area health services}

We sent the regional report draft template and the questionnaire to 22 people who were nominated by the areas as contacts because of their role within the service and/or their experience. All 17 area health services were represented in this sample. Area contacts included people in a variety of positions such as: the directors of public health units and divisions of population health; epidemiologists; and planning, statistics, research, and health promotion professionals.

\section{Development of the final regional report template}

The responses to the questionnaire were collated and considered by a team that consisted of the Health Survey Program Manager, an epidemiologist, a systems developer and a biostatitician. Suggestions were assessed and, where appropriate, incorporated into the final regional report template.

\section{TABLE 1}

\section{POTENTIAL INDICATORS FOR THE AREA HEALTH} SERVICE REGIONAL REPORTS

Indicators suggested in the draft template available from

1997, 1998, and 2002 health surveys

- alcohol risk drinking behaviour

- fruit intake

- vegetable intake

- physical activity

- smoking

- self-rated health status

- diabetes

- overweight and obesity

- psychological distress

- health services utilisation

Additional indicators requested and available from 1997,

1998, and 2002 health surveys

- smoke-free households

- asthma

- oral health (no natural teeth missing)

- difficulty getting care when needing it

- emergency department care rating

- hospital care rating

Additional indicators requested and available from 2002 and 2003 health surveys

- influenza immunisation

- pneumococcal immunisation

- attended a community event

- trust most people

- visit neighbours

Source: NSW Health Survey Program, Centre for Epidemiology and Research, NSW Department of Health.

\section{RESULTS}

\section{Survey results}

Eighteen completed questionnaires were returned. Some areas that had nominated more than one contact returned a single questionnaire by collating the views of their contacts. In other areas each contact returned a questionnaire. Questionnaires were received from 16 area health services, a response rate of 94 per cent.

\section{Ease of understanding}

Most respondents indicated that the draft template was 'very easy to understand'. However, only 7 indicated that, in their experience, health service planning and development staff would find the reports 'very easy to understand' and only 3 area contacts thought that policy development staff would find the reports 'very easy to understand' (Table 2). A minority of respondents thought the reports would be hard to understand for any category of staff.

\section{Indicators required}

In addition to the 10 indicators listed for inclusion in the regional report, all respondents requested the inclusion of at least 1 from a list of 7 possible additional topics. 
TABLE 2

EASE OF UNDERSTANDING THE WAY THE INFORMATION WAS PRESENTED INTHE REGIONAL REPORT DRAFT TEMPLATE BY DIFFERENT TYPES OF STAFF AS PERCIEVED BY THE NOMINATED AREA CONTACTS

\begin{tabular}{|c|c|c|c|c|c|c|}
\hline \multirow[t]{2}{*}{ Ease of understanding } & \multicolumn{2}{|c|}{$\begin{array}{l}\text { Area contact } \\
\text { respondent }\end{array}$} & \multicolumn{2}{|c|}{$\begin{array}{l}\text { Health service planning } \\
\text { and development staff }\end{array}$} & \multicolumn{2}{|c|}{ Policy development staff } \\
\hline & $n$ & $\%$ & $n$ & $\%$ & $n$ & $\%$ \\
\hline Very easy to understand & 15 & 83 & 7 & 39 & 3 & 17 \\
\hline Easy to understand & 3 & 17 & 10 & 56 & 14 & 78 \\
\hline Hard to understand & 0 & 0 & 1 & 5 & 1 & 5 \\
\hline Very hard to understand & 0 & 0 & 0 & 0 & 0 & 0 \\
\hline Total & 18 & 100 & 18 & 100 & 18 & 100 \\
\hline
\end{tabular}

Source: NSW Health Survey Program, Centre for Epidemiology and Research, NSW Department of Health.

Over a third of respondents (7) requested that all 7 possible additional topics be included. The topics in highest demand were an asthma indicator (15 respondents), followed by an indicator of influenza immunisation in older people and a social capital indicator (14 respondents each). Over half of the respondents requested the inclusion of an oral health indicator, an environmental tobacco smoke indicator, a indicator of pneumococcal immunisation in older people, and a food security indicator.

The additional topics of asthma and environmental tobacco smoke requested for inclusion in the regional report were assessed as suitable for inclusion by the panel from 2002 onwards. Social capital indicators, and influenza and pneumococcal immunisation indicators, could be included in the reports from 2003 onwards.

\section{Usefulness of the report}

All respondents said the regional reports would be of some use in monitoring the health of their populations and developing population health policy (Table 3). One respondent added that the reports would be useful for planning population and community health services.

\section{Suggestions}

There were several comments and suggestions for improving the presentation of information in the reports. All suggestions were considered by the panel and adopted, if possible (Table 4).

The final template of the regional report includes an introductory page, which lists the indicators in the report. Each indicator is presented in graphic and tabular form over 2 pages (Figure 1). NSW Health staff can access the regional reports on the NSW Department of Health intranet at http://internal.health.nsw.gov.au/public-health/ research/surveys_and_monitoring/health_survey_ program/ahs_report.html.

\section{DISCUSSION}

The regional reports were perceived as easy to understand and useful, in particular when monitoring the health of populations and supporting the development of population health policy. Respondents provided useful suggestions to improve the regional reports.

The high response rate suggests that there is interest in the NSW Health Survey Program. However, as the responders are a small sample of the potential users of health survey data in the areas, their views may not be representative of a broader spectrum of potential users.

As much as possible, suggestions made to improve the reports were incorporated. Those suggestions that were unable to be incorporated were related to sample size rather than presentation of the reports, including the provision of prevalence estimates for local government area and specific population groups. The Health Survey Program understands the importance of having data for regional requirements ${ }^{7}$ and annually collects sufficient data to report at the area health service level. Reporting by local government area and specific population groups may be possible over several years, and these variables are currently available on the Health Outcomes Information Statistical Toolkit (HOIST), which is maintained by the Centre for Epidemiology and Research within the NSW Department of Health. ${ }^{8}$

\section{CONCLUSION}

Consultation with the areas helped us develop a standardised regional report that provides areas with timely, useful, and understandable population health data. Further feedback from the areas about the published reports will also assist us to further improve their access to, and use of, survey data to support population health.

\section{ACKNOWLEDGMENTS}

We would like to thank the area contacts for the NSW Health Survey Program for their feedback during the consultation process.

\section{REFERENCES}

1. Jorm L, Puech M. Strategy for population health surveillance in NSW. Sydney: Epidemiology and Surveillance Branch, NSW Department of Health, 1997. 
TABLE 3

USEFULNESS OF INFORMATION PROVIDED IN THE REGIONAL REPORT DRAFT TEMPLATE FOR EACH OF ITS INTENDED PURPOSES, AS REPORTED BY THE NOMINATED AREA CONTACTS

\begin{tabular}{|c|c|c|c|c|c|c|}
\hline \multirow[t]{2}{*}{ Usefulness } & \multicolumn{2}{|c|}{$\begin{array}{l}\text { Monitoring the health } \\
\text { of populations }\end{array}$} & \multicolumn{2}{|c|}{$\begin{array}{c}\text { Planning and development } \\
\text { of health services }\end{array}$} & \multicolumn{2}{|c|}{$\begin{array}{l}\text { Development of population } \\
\text { health policy }\end{array}$} \\
\hline & $n$ & $\%$ & $n$ & $\%$ & $n$ & $\%$ \\
\hline Very useful & 9 & 50 & 4 & 22 & 8 & 44 \\
\hline Quite useful & 5 & 28 & 7 & 39 & 5 & 28 \\
\hline Somewhat useful & 4 & 22 & 7 & 39 & 5 & 28 \\
\hline Not useful & 0 & 0 & 0 & 0 & 0 & 0 \\
\hline Total & 18 & 100 & 18 & 100 & 18 & 100 \\
\hline
\end{tabular}

Source: NSW Health Survey Program, Centre for Epidemiology and Research, NSW Department of Health.

\section{TABLE 4}

SUMMARY OF RESPONDENTS'SUGGESTIONS AND ACTIONTAKEN

\begin{tabular}{|c|c|c|}
\hline Suggestions for improvement & $\begin{array}{l}\text { Addressed in } \\
\text { final template }\end{array}$ & Details \\
\hline Include confidence intervals in graphs & Partially & Confidence Intervals included in tables \\
\hline $\begin{array}{l}\text { Provide an explanation of what confidence intervals are } \\
\text { as levels of experience and training in epidemiology vary } \\
\text { among staff }\end{array}$ & Yes & Explanation provided on introduction page \\
\hline $\begin{array}{l}\text { Include a comparison with NSW in the graph of the } \\
\text { indicator by age group }\end{array}$ & Yes & $\begin{array}{l}\text { Changes template to } 2 \text { pages per indicator to } \\
\text { accommodate change }\end{array}$ \\
\hline Label all items in tables and graphs more clearly & Yes & $\begin{array}{l}\text { Increased size of labels and changed template } \\
\text { to } 2 \text { pages per indicator to improve clarity }\end{array}$ \\
\hline $\begin{array}{l}\text { Include an explanation about the calculation of estimated } \\
\text { numbers }\end{array}$ & No & Self-explanatory \\
\hline Include the wording of the questions & Yes & $\begin{array}{l}\text { Question wording included in note below graph } \\
\text { and table }\end{array}$ \\
\hline List the responses that define the indicators & Yes & Indicator defined in note below graph and table \\
\hline Include age-standardised prevalence rates & No & $\begin{array}{l}\text { Data weighted to age-sex structure of the area } \\
\text { population. }\end{array}$ \\
\hline Ensure timely dissemination of the reports & Yes & $\begin{array}{l}\text { Automated process and disseminated as internal } \\
\text { electronic reports }\end{array}$ \\
\hline $\begin{array}{l}\text { Provide information at the local government area level } \\
\text { within the area }\end{array}$ & No & Sample not large enough \\
\hline Provide information on Aboriginal people within the area & No & Sample not large enough, and not representative \\
\hline $\begin{array}{l}\text { Ensure timely access to area data and data analysis } \\
\text { tools and programs }\end{array}$ & Yes & $\begin{array}{l}\text { Datasets including indicator variables and } \\
\text { analysis tools provide through HOIST. Health } \\
\text { survey SAS programs available on request }\end{array}$ \\
\hline
\end{tabular}

2. Public Health Division. Electronic Report on the 1997 and 1998 NSW Health Surveys. Sydney: NSW Department of Health, 2000. Available online at www.health.nsw.gov.au/ public-health/nswhs/hsindex.htm.

3. Williamson M, Baker D, Jorm L. The NSW Health Survey Program: overview and methods, 1996-2000. N S W Public Health Bull 2001; 12(S-2).

4. Eyeson-Annan M. Continuous data collection under the NSW Health Survey Program: What will it mean? N S W Public Health Bull 2001; 12(8): 235-237.

5. Banks C, Eyeson-Annan M. Uses of NSW Health Survey Program data: a survey of users. N S W Public Health Bull 2001; 12(8): 214-220.
6. Muscatello D. Program for Enhanced Population Health Infostructure (PEPHI): a report of responses to the November 2000 discussion paper. N S W Public Health Bull 2002; 13(S-2).

7. Australian Institute of Health and Welfare. Issues and priorities in the surveillance and monitoring of chronic diseases in Australia. Canberra: AIHW, 2002.

8. Population Health Division. Health Outcomes Information Statistical Toolkit (HOIST). Sydney: Centre for Epidemiology and Research, NSW Department of Health. Available online at www.health.nsw.gov.au/public-health/epi/hoist.html. 


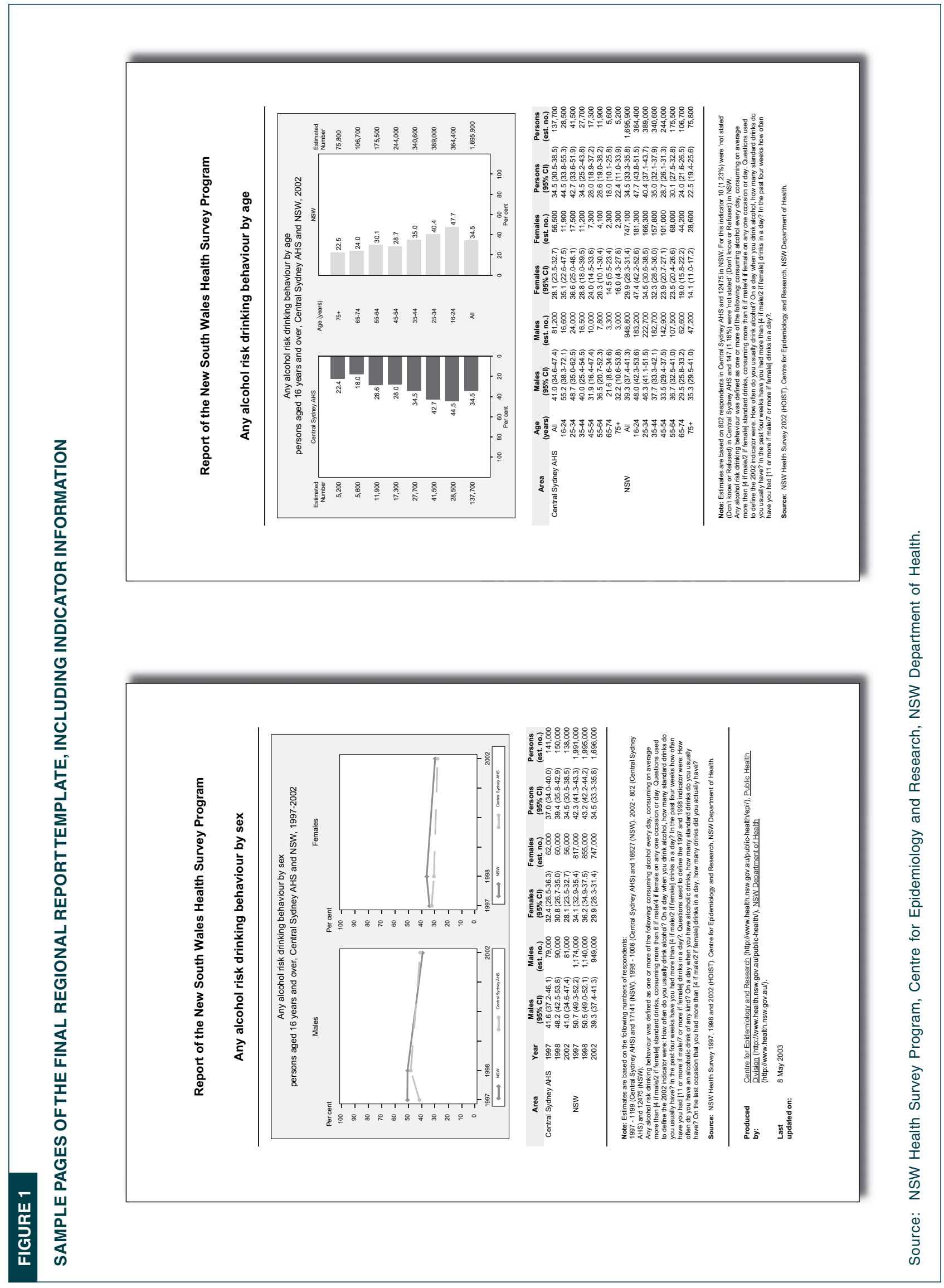

